\title{
Treatment Failure Reason
}

National Cancer Institute

\section{Source}

National Cancer Institute. Treatment Failure Reason. NCI Thesaurus. Code C102721.

The reason the drug or therapy was unsuccessful in treating the condition. 